\title{
How should health service organizations respond to diversity? A content analysis of six approaches
}

\author{
Conny Seeleman ${ }^{1 *}$, Marie-Louise Essink-Bot ${ }^{1}$, Karien Stronks $^{1}$ and David Ingleby ${ }^{2}$
}

\begin{abstract}
Background: Health care organizations need to be responsive to the needs of increasingly diverse patient populations. We compared the contents of six publicly available approaches to organizational responsiveness to diversity. The central questions addressed in this paper are: what are the most consistently recommended issues for health care organizations to address in order to be responsive to the needs of diverse groups that differ from the majority population? How much consensus is there between various approaches?
\end{abstract}

Methods: We purposively sampled six approaches from the US, Australia and Europe and used qualitative textual analysis to categorize the content of each approach into domains (conceptually distinct topic areas) and, within each domain, into dimensions (operationalizations). The resulting classification framework was used for comparative analysis of the content of the six approaches.

Results: We identified seven domains that were represented in most or all approaches: organizational commitment, empirical evidence on inequalities and needs, a competent and diverse workforce, ensuring access for all users, ensuring responsiveness in care provision, fostering patient and community participation, and actively promoting responsiveness. Variations in the operationalization of these domains related to different scopes, contexts and types of diversity. For example, approaches that focus on ethnic diversity mostly provide recommendations to handle cultural and language differences; approaches that take an intersectional approach and broaden their target population to vulnerable groups in a more general sense also pay attention to factors such as socio-economic status and gender.

Conclusions: Despite differences in labeling, there is a broad consensus about what health care organizations need to do in order to be responsive to patient diversity. This opens the way to full scale implementation of organizational responsiveness in healthcare and structured evaluation of its effectiveness in improving patient outcomes.

Keywords: Equity, Diversity, Quality of care, Cultural competence, Healthcare organization, Responsiveness

\section{Background}

Health service users belonging to groups that differ from the majority population, such as migrants and ethnic minorities, often receive poorer care than majority users. Variously described as health care 'disparities', 'inequalities' or 'inequities', these problems in health care have been well documented in the United States $[1,2]$ and are increasingly being recognized in other countries [3-5].

\footnotetext{
* Correspondence: m.c.seeleman@amc.uva.nl

'Department of Public Health, Academic Medical Center, University of Amsterdam, P.O. Box 227001100 DE Amsterdam, The Netherlands Full list of author information is available at the end of the article
}

The evidence demonstrating health care inequalities implies that health services need to adapt in order to increase their accessibility and quality for minority service users. Promoting responsiveness to diversity requires interventions at individual, organizational and system level. Individual caregivers need specific knowledge, skills and attitudes [6, 7]. For health care organizations, promoting diversity responsiveness involves putting into place specific service policies and practices [8]. Diversity responsiveness at the level of entire health systems includes measures at national or state level, for example by legislation guaranteeing financial access to health care. 
In the US, responsiveness to diversity at organizational level has been promoted through the CLAS standards (Standards for Culturally and Linguistically Appropriate Services) [9], designed to address the needs of racial, ethnic, and linguistic population groups that experience disparities in health service provision $[10,11]$. In Europe, diversity responsiveness recommendations have been published under the heading of 'migrant-friendliness' [12], 'intercultural opening' [13], 'transcultural competence' [14] or 'difference sensitivity' [15], the latter targeting 'vulnerable groups' including but not confined to ethnic and cultural minority groups.

Responsiveness to ethnic and cultural diversity has for several decades been referred to as 'cultural competence' [16]. Regarding terminology, the term cultural competence has often been criticized in the literature [17, 18], mainly because of limited operationalizations focusing too exclusively on expert knowledge about minority populations. Critics correctly point out that such knowledge may lead to stereotyping and a focus on the 'otherness' of patients. However, many cultural competence frameworks have a broader operationalization, emphasizing the triad of skills, attitudes and knowledge [6].

The development of uniform terminology and definitions to describe culturally competent or diversity responsive health care is considered as key for effective evidence-based development, implementation and evaluation of diversity responsive health care $[17,19]$. Therefore, we qualitatively analyzed and compared six approaches to organizational diversity responsiveness in health care. We explored whether the lack of agreement about terminology between such approaches reflects important differences at the level of content, or whether there is a reasonable degree of consensus about the measures that organizations should take to adapt health services to the needs of diverse patient populations. The paper addresses the following questions:

1. On which domains of health service provision do the approaches focus?

2. How much agreement is there about important domains?

3. What are the most consistently recommended elements for organizations to address in order to be responsive to diversity?

\section{Method}

\section{Sampling strategy of approaches}

In recent years many guidelines or recommendations for increasing organizational responsiveness to diversity have been published internationally by both public and private bodies. We explicitly did not aim at conducting a comprehensive review of all available approaches. Instead, we purposively sampled six approaches to diversity responsiveness at organizational level using the following criteria:

- the approach was developed for wider than local use by a single health care organization;

- it was developed by an authoritative public body, such as a health ministry or a recognized group of experts;

- it was publicly available;

- the final selection included approaches from the US, Australia and Europe.

We started with the CLAS Standards [9] and continued adding approaches one by one, searching the published and grey public literature in an iterative process, until saturation was reached (i.e. adding a new approach did not provide new information). The sampling was conducted in 2012.

The following approaches were sampled: 1) CLAS Standards - National Standards for Culturally and Linguistically Appropriate Services in Health Care (further referred to as: CLAS) developed by the Office of Minority Health, part of the U.S. Department of Health and Human Services [9]; 2) Advancing Effective Communication, Cultural Competence, and Patient- and Family Centered Care: A Roadmap for Hospitals (further referred to as JCR), developed by the US Joint Commission [20]; 3) Cultural Responsiveness Framework. Guidelines for Victorian health services (further referred to as CRF) developed by the Victorian Government, Department of Health, Australia [21]; 4) Recommendation of the committee of ministers to member states on mobility, migration and access to health care (further referred to as COER) of the Council of Europe [22, 23]; 5) The Equality Delivery System (further referred to as EDS) for the NHS, UK [24]; 6) Standards for Equity in Health Care for Migrants and other Vulnerable Groups (further referred to as EQS) developed by the WHO-HPH Task Force on Migrant-Friendly and Culturally Competent Healthcare [25]. Table 1 briefly describes each approach and clarifies our reasons for including the approach in our study.

In May 2013 the Enhanced CLAS Standards were published, entitled "National Standards for Culturally and Linguistically Appropriate Services in Health and Health Care: A Blueprint for Advancing and Sustaining CLAS Policy and Practice" [11]. A comparison of the new Standards with the original version showed that the underlying approach was virtually identical to that which informed the first edition. The aim of the revision was to increase the effectiveness of the Standards, by explaining them more clearly, ensuring that they reflected recent developments, and aligning them with other initiatives such as the Affordable Care Act and the 
Table 1 Description of the six approaches on responsive health care that were included

1. CLAS Standards - National Standards for Culturally and Linguistically Appropriate Services in Health Care (CLAS) [ 9 ]. These standards were developed by the Office of Minority Health, part of the U.S. Department of Health and Human Services. Some of the standards have the status of mandates, meaning that they are Federal requirements for all health care organizations that receive Federal funds; others are purely recommendations. We included the CLAS standards because they were the first one and probably the most comprehensive and influential approach currently in use. In May 2013 the Enhanced CLAS Standards were published [ 11 ]. Although largely similar, there are some differences of emphasis between the original and the Enhanced CLAS Standards:

- The revised CLAS acknowledged that in order to address disparities in health care (for any target group), we need to go beyond cultural issues and deal with other (e.g., social, psychological) issues.

- In the vision on responsive care some slight changes of emphasis could be found, such as a shift from regarding diversity as a 'group' characteristic to 'appreciating the diversity of individuals'. The enhanced CLAS also places more emphasis on the importance of 'patient- and family centred care', thus bringing it more into line with the JC Roadmap.

2. Advancing Effective Communication, Cultural Competence, and Patient- and Family Centered Care: A Roadmap for Hospitals (JCR) [ 20 ]. This 'Roadmap' has been developed by the Joint Commission (JC), an independent, not-for-profit organization which accredits and certifies health care organizations in the United States. The Roadmap was developed in addition to existing JC requirements "to inspire hospitals to integrate concepts from the fields of communication, cultural competence, and patient- and family-centered care into their organizations." We included the JC Roadmap because of the global influence of $\mathrm{JC}$ and the Joint Commission International $(\mathrm{JCl})$ accreditation program on health care organizations through their accreditation programs (applied in over 50 countries). JC developed its own framework of recommendations in which cultural competence is embedded within effective communication and patient- and family centred care. Please note that 1) other existing JC requirements also include issues related to those issues discussed in the Roadmap, and 2) that the national Joint Commission Standards are different from the Standards of the Joint Commission International.

3. Cultural Responsiveness Framework. Guidelines for Victorian health services (CRF) by the Rural and Regional Health and Aged Care Services, Victorian Government, Department of Health (Australia) [ 21 ]. The CRF was developed to replace the Health Service Cultural Diversity Plans (HSCDPs) which since 2006 have required all Victorian health services to develop and implement policies for ethnic diversity in care. The intention of the CRF is to consolidate multiple requirements for reporting on cultural diversity initiatives within health services. All Victorian health services are required to submit plans and achievements according to the standards and measures in the CRF to the Statewide Quality Branch. We included the CRF because it has been disseminated and made compulsory in a large health care system in Australia.

4. Recommendation of the committee of ministers to member states on mobility, migration and access to health care (COER) of the Council of Europe $[22,23]$. The Council of Europe is an international organization set up "to achieve a greater unity between its members for the purpose of safeguarding and realizing the ideals and principles which are their common heritage and facilitating their economic and social progress" [ 37 ]. We included the COER because it has been endorsed by the Health Ministers of the 47 member states of the Council of Europe. The document is aimed at ministerial level, therefore it includes recommendations that have consequences for the whole health system. These recommendations focus on the diversity responsiveness in the context of migrants and their children. To make comparisons possible we have only included the recommendations at organizational level in our analysis.

5. Equality Delivery System (EDS) for the NHS [ 24 ]. EDS originates from the Equality and Diversity Council within the British National Health Service (NHS). It is designed to help NHS organizations to comply with the 'Public Sector Equality Duty' (PSED) of the Equality Act. This act "requires public bodies to consider all individuals when carrying out their day to day work - in shaping policy, in delivering services and in relation to their own employees" [ 38 ]. EDS is made available to the NHS as an optional tool. It was included because it is a European instrument which has been disseminated in a large health care system.

6. Equity Standards (EQS) of the Task Force on Migrant-Friendly and Culturally Competent Healthcare [ 25 ]. These Standards were developed by a group of mainly European experts set up within WHO's Health Promoting Hospitals network. The Equity Standards are a self-assessment instrument to enable health care organizations to carry out an 'equity evaluation' against a set of standards. The instrument was piloted in 10 European countries, as well as in two non-European ones. The Equity Standards were included because of the broad international context in which they were developed.

work of the Joint Commission. Some differences of emphasis are described in Table 1 . The version of CLAS used in this paper is the original one: we considered the original CLAS Standards as the oldest and most influential of all approaches and we did not feel the changes made in the enhanced version were fundamental enough to warrant a separate analysis.

\section{Developing an analytical framework for the present analysis \\ Encoding of content}

1. An inductive approach was used. We first analyzed CLAS [9] by grouping the 14 standards into conceptually distinct topic areas (domains). We subsequently identified dimensions that showed the concrete operationalization within each domain.

2. A second approach was selected and its content was subsumed under the domains and dimensions identified in Step 1, new ones being created where necessary.

3. The remaining four approaches were treated in the same way.

4. The resulting framework of domains and dimensions was critically reviewed and discussed until consensus was reached by three of the authors in order to remove ambiguities and overlap. 


\section{Comparison of content}

Categorizing the content of the approaches in this analytical framework enabled us to see at a glance whether certain domains were unique to, or absent from, particular approaches. Within each domain, it revealed the differences in the ways in which approaches operationalized the domain. We listed the differences between them as well as their commonalities. MCS performed the analysis; results were independently reviewed by MLE-B and JDI. Disagreements were resolved by discussion.

\section{Ethics statement}

An ethics statement was not required for this work.

\section{Results}

This section starts with background information on the six approaches. We then provide an overview and analysis of their content, classified according to the domains and dimensions of the analytical framework. We then describe the similarities and differences between the six approaches.

\section{Background information}

Table 2 provides background information on the six approaches, listed with their acronyms.

As their aim, the approaches refer to reducing or eliminating existing inequalities in health and service provision between different populations (CLAS, COER, EQS), as well as improving outcomes for individual patients (JCR, CRF, EDS). Some approaches (CLAS, COER, EQS) start from human rights principles, regarding inequalities between groups as injustices which should be eliminated. JCR considers equality of patient outcomes as a performance indicator, while CRF and EDS combine both starting points. Two unique aims also emerge: CRF aims to enhance the cost-effectiveness of health service delivery, and EDS aims to create better working environments for staff.

In their vision on responsive care, three approaches directly invoke the concept of 'cultural competence'. CLAS refers to the classic definition of cultural competence (Cross et al., 1989) [16] and explicitly emphasizes language issues. For JCR, cultural competence is one of three fundamental concepts on which the Roadmap elaborates (the other concepts being 'effective communication' and 'patient and family centered care'). JCR and CLAS operationalize cultural competence similarly. CRF introduces another label: 'culturally responsive care', but the vision implied is very similar to that of CLAS and JCR. A common characteristic of these three approaches is their emphasis on 'culture' in the labeling of their vision.

In the other three approaches the emphasis is not on 'culture' but on 'equity' or 'equality'. COER refers to "equitable access to health care of appropriate quality": in relation to service delivery, by referring to "improving the adaptation of health service provision to the needs, culture and social situation of migrants". EDS does not provide a definition of its concept of equality, but relates it to the pursuit of quality, which in turn is defined as recognizing the needs and circumstances of all (both patients and staff) and ensuring accessibility, appropriateness, safety and effectiveness for patients. EQS explicitly distances itself from the concept of 'cultural competence', instead highlighting Whitehead's definition of equity in health: "equal access to available care for equal need; equal utilization for equal need; equal quality of care for all" [26].

The target population of each approach refers to the user groups envisaged by the authors as beneficiaries. CLAS, JCR and CRF refer to the target population in terms of race, ethnicity, culture or language, while EDS and EQS also include gender, age, disability, religion, sexual orientation, transgender status (both EDS and EQS); marriage and civil partnership, pregnancy and maternity, nationality (only EDS); socio-economic status and minority status (EQS). COER focuses explicitly on migrants, a category that is not mentioned explicitly in CLAS, JCR, CRF or EDS. However, COER uses the term migrant "in a very broad sense, referring not only to those who change their country of residence voluntarily but also to asylum seekers, refugees and victims of human trafficking. Since the consequences of migration may also extend beyond the first generation, second and later generations are also discussed. In the case of Internally Displaced Persons, internal migrants are also included". There is thus considerable overlap between the category of 'migrants' as defined by COER and the term 'ethnic minorities' used in other approaches.

\section{'Horizontal' analysis (comparison of domain content across approaches) \\ Organizational commitment}

We classified elements of the various approaches in this domain if they mentioned commitment at management level to responsiveness to diversity. Two dimensions were found: policy and leadership and measurement of performance.

\section{Policy and leadership}

All six approaches maintain that organizations must make an explicit commitment to developing responsive care, rather than merely permitting individual initiatives that are not structurally embedded in the organization. In COER this requirement is implied by insistence on a 'whole organization approach'. Commitment can either take the form of an explicit plan (CLAS, EQS), which sets out how the organization intends to organize and 
Table 2 Background information on the six approaches

\begin{tabular}{|c|c|c|c|c|c|c|}
\hline $\begin{array}{l}\text { Background information } \\
\text { on model }\end{array}$ & CLAS Standards (CLAS) & $\begin{array}{l}\text { Joint Commission Roadmap } \\
\text { (JCR) }\end{array}$ & $\begin{array}{l}\text { Cultural Responsiveness } \\
\text { Framework (CRF) }\end{array}$ & $\begin{array}{l}\text { Council of Europe } \\
\text { Recommendations } \\
\text { (COER) }\end{array}$ & $\begin{array}{l}\text { Equality Delivery System } \\
\text { (EDS) }\end{array}$ & Equity Standards (EQS) \\
\hline origin & $\begin{array}{l}\text { US dept of Health and } \\
\text { Human Services; Office } \\
\text { of Minority health (U.S.) }\end{array}$ & The Joint Commission (U.S.) & $\begin{array}{l}\text { Victorian Government; Dept. of } \\
\text { Health (Australia) }\end{array}$ & $\begin{array}{l}\text { Council of Europe; } \\
\text { The committee of } \\
\text { ministers (Europe) }\end{array}$ & $\begin{array}{l}\text { The National Health Services } \\
\text { (NHS); The Equality and } \\
\text { Diversity Council (U.K.) }\end{array}$ & $\begin{array}{l}\text { Health Promoting Hospitals; } \\
\text { Task Force on Migrant- } \\
\text { Friendly and Culturally } \\
\text { Competent } \\
\text { Health care (Europe) }\end{array}$ \\
\hline year & 2001 & 2010 & 2009 & 2011 & 2011 & 2013 \\
\hline aim & $\begin{array}{l}\text { *ensure equitable and } \\
\text { effective treatment in a } \\
\text { culturally and linguistically } \\
\text { appropriate manner } \\
{ }^{*} \text { correct inequities } \\
{ }^{*} \text { more responsive services } \\
\text { *elimination of racial and } \\
\text { ethnic health disparities } \\
\text { *inform, guide and facilitate } \\
\text { culturally and linguistically } \\
\text { appropriate care }\end{array}$ & $\begin{array}{l}\text { *improve overall safety and } \\
\text { quality of care } \\
\text { *integrate concepts from } \\
\text { communication, cultural } \\
\text { competence and patient- } \\
\text { centered care fields into } \\
\text { hospitals }\end{array}$ & $\begin{array}{l}\text { *better links between access, } \\
\text { equity, quality and safety } \\
\text { *better health outcomes for } \\
\text { culturally and linguistically } \\
\text { diverse (CALD) populations } \\
\text { *enhance cost effectiveness } \\
\text { of service provision } \\
\text { *track organizations' } \\
\text { improvement; align cultural } \\
\text { responsiveness (CR) with } \\
\text { existing standards; develop } \\
\text { benchmarks }\end{array}$ & $\begin{array}{l}{ }^{*} \text { Equitable access } \\
\text { to health care of } \\
\text { appropriate quality }\end{array}$ & $\begin{array}{l}\text { *better outcomes for patients } \\
\text { and communities, better } \\
\text { working environments for staff } \\
\text { *improve equality performance } \\
\text { *review equality performance } \\
\text { *a tool to comply to the } \\
\text { 'public sector Equality Duty'. }\end{array}$ & $\begin{array}{l}\text { *ensure equitable and } \\
\text { accessible health care } \\
{ }^{*} \text { reduce disparity in health } \\
\text { care } \\
\text { *an Equity self-assessment } \\
\text { by health care organizations }\end{array}$ \\
\hline vision & $\begin{array}{l}{ }^{*} \text { cultural and linguistic } \\
\text { competence } \\
{ }^{*} \text { culturally and linguistically } \\
\text { appropriate services (CLAS) }\end{array}$ & $\begin{array}{l}\text { *effective communication } \\
\text { (EC) } \\
{ }^{*} \text { cultural competence } \\
\text { (CC) } \\
{ }^{*} \text { patient- and family- } \\
\text { centered care (PFCC) }\end{array}$ & ${ }^{*}$ cultural responsiveness $(\mathrm{CR})$ & $\begin{array}{l}{ }^{*} \text { improving the } \\
\text { adaptation of } \\
\text { health service } \\
\text { provision to the } \\
\text { needs, culture and } \\
\text { social situation of } \\
\text { migrants }\end{array}$ & $\begin{array}{l}\text { *equality for patients and staff } \\
{ }^{*} \text { personal, fair and diverse } \\
\text { services and workplaces }\end{array}$ & *promoting equity \\
\hline target population & $\begin{array}{l}\text { *inclusive of all patients } \\
\text { *especially racial, ethnic, and } \\
\text { linguistic populations that } \\
\text { experience unequal access }\end{array}$ & $\begin{array}{l}\text { *no target group, } \\
\text { recommendations address } \\
\text { 'issues' in health care (e.g. } \\
\text { language, culture etc.) }\end{array}$ & $\begin{array}{l}{ }^{*} \text { Culturally and linguistically } \\
\text { diverse populations (CALD) }\end{array}$ & ${ }^{*}$ migrants & ${ }^{*}$ protected groups & $\begin{array}{l}\text { *migrants and all other } \\
\text { vulnerable groups }\end{array}$ \\
\hline target organization-type & $\begin{array}{l}\text { *health care organizations } \\
\text { *policymakers, accreditation } \\
\text { agencies, purchasers, patients, } \\
\text { advocates, educators, health } \\
\text { care community in general }\end{array}$ & *hospitals & *all Victorian health services & $\begin{array}{l}\text { *governments of } \\
\text { CoE member } \\
\text { states }\end{array}$ & $\begin{array}{l}\text { *NHS commissioners and } \\
\text { providers }\end{array}$ & *health care organizations \\
\hline structure & $\begin{array}{l}\text { *14 standards in three types: } \\
\text { mandates (4), guidelines (9), } \\
\text { and recommendations (1) } \\
\text { *three themes: culturally } \\
\text { competent care, language } \\
\text { access services, and } \\
\text { organizational supports for } \\
\text { cultural competence }\end{array}$ & $\begin{array}{l}\text { *54 recommendations } \\
\text { structured around main } \\
\text { points along the care } \\
\text { continuum } \\
\text { *aspects of the care } \\
\text { continuum: admission; } \\
\text { assessment; treatment; } \\
\text { end of life care; discharge } \\
\text { and transfer; organization } \\
\text { readiness }\end{array}$ & $\begin{array}{l}\text { *six standards across four } \\
\text { domains, divided in measures } \\
\text { and sub-measures (both } \\
\text { quantitative and qualitative) } \\
\text { *Standards: a whole organization } \\
\text { approach; leadership; interpreters; } \\
\text { inclusive practice; consumer/ } \\
\text { community involvement; staff. } \\
\text { *Four domains: organizational } \\
\text { effectiveness; risk management; } \\
\text { consumer participation; effective } \\
\text { workforce }\end{array}$ & $\begin{array}{l}\text { *14 recommendations, } \\
\text { specified in } 31 \\
\text { sub-recommendations. }\end{array}$ & $\begin{array}{l}\text { *18 outcomes grouped into } \\
\text { four goals; nine steps for } \\
\text { implementation } \\
\text { *EDS goals: better health } \\
\text { outcomes for all; improved } \\
\text { patient access and experience; } \\
\text { empowered, engaged, and } \\
\text { well-supported staff; inclusive } \\
\text { leadership at all levels }\end{array}$ & $\begin{array}{l}\text { *five main standards, } \\
\text { divided in substandards } \\
\text { and measurable elements } \\
\text { *main standards: equity in } \\
\text { policy; equitable access and } \\
\text { utilization; equitable quality } \\
\text { of care; equity in participation; } \\
\text { promoting equity }\end{array}$ \\
\hline
\end{tabular}

adaptation of

health service

provision to the

needs, culture and

migrants

*migrants

*governments of

COE member

*NHS comr

"equality for patients and staf

*personal, fair and diverse

better outcomes for patien

working environments for $s$

equality performance

"public sector Equality Duty'.

*migrants and all other

\section{ns}

(n)

.


guarantee responsiveness, or a policy of good leadership (JCR, EDS), or both (CRF).

'Good leadership' is explicitly committed to achieving responsive care and promotes this within the organization (JCR, EDS): leaders take responsibility for reaching this goal (CRF). All approaches emphasize that plans for change should be integrated in existing organizational policies and processes. EQS additionally promotes a 'proactive' approach: in all its plans, the organization should anticipate the effect the plans will have on accessibility and quality of care for vulnerable groups.

\section{Measuring and improving performance}

All approaches regard it as essential that organizations measure their performance in providing responsive services (e.g. outcomes of treatment for different groups), with the aim of identifying necessary improvements, taking action, and assessing the organization's progress in providing responsive care. CLAS, EDS and EQS further emphasize that performance measurement should be a continuous activity, incorporated in regular performance measurement systems. The approaches differ regarding the variables that should be measured: some focus on quality of care, some on accessibility and some on both (see also the domain 'collecting data' for the data sources to be used in measuring and improving performance). CRF is the only approach stipulating mandatory indicators for measuring organizational cultural responsiveness. These have to be submitted by affiliated organizations and are also used for benchmarking.

\section{Collecting data}

The second domain we identified concerns the collection of data, not as an end in itself but in order to inform the organization about equity of access to and quality of care delivered in their organization and to identify special needs or opportunities for improvement. Two types of data are distinguished, concerning the population at large and the organization's own users.

\section{Data on the population at large}

Five approaches (CLAS, JCR, CRF, EDS, EQS) recommend collecting data on the community or catchment area in order to adapt services to the needs thus identified. Organizations can use information that is already available, but CLAS and EDS also give organizations an active role in collecting these data themselves. Such data include demographic variables (e.g. age, gender, ethnicity), characteristics potentially affecting service use (e.g. language proficiency, health literacy), health status and exposure to health risks. In COER the importance of empirical evidence is strongly emphasized: governments are urged to collect it "in partnership with relevant organizations".

\section{Data on the patient population}

Patients' files can serve as a source of data on ethnicity, race, language and other characteristics considered relevant for quality of care. For CLAS, JCR, CRF, and EQS these data are considered important in order to identify and monitor health and health care inequalities. For CLAS, JCR and EQS, information in patients' files on individual characteristics associated with ethnic minority status (e.g. proficiency in the majority language) also enables adaptation of care to the needs of an individual patient. Additionally CLAS, JCR, CRF, EDS and EQS emphasize that outcome measures and patient feedback systems must be able to analyze results according to diversity characteristics. The approaches differ in the types of data they recommend organizations to collect in this respect.

\section{Staff/Workforce}

The third domain concerns the staff or workforce of the organization. Two dimensions can be distinguished: staff competencies and diversity in the workforce.

\section{Staff competencies}

Staff competencies in delivering responsive care, and the importance of education and training, are central themes in all approaches. CRF and EDS describe a comprehensive approach to improving confidence and competence among staff, for example through personal development programs (EDS) and adapted HRM policies (CRF). CLAS, CRF, COER and EQS emphasize that all staff should be trained (CLAS even includes affiliated and subcontracted staff); CLAS, CRF and EQS also recommend monitoring the effects of training. CLAS recommends separate training in the provision of responsive care; JCR recommends the incorporation of such training in the existing curriculum, while COER and EQS support both. The approaches vary in the amount of information they provide on the content of training.

\section{Diversity in the workforce}

According to CLAS, JCR and COER, diversity among staff members is desirable for furthering responsiveness to patient diversity. Two arguments are given for the importance of staff diversity. The first is general: the workforce should be representative of the general population (CLAS, COER). The second is more specific: staff diversity is considered to further equity by making possible a higher degree of linguistic and ethnic concordance between patients and staff (CLAS, JCR). EDS and EQS discuss this issue from the perspective of equality among staff and include objectives for inclusive Human Resource policies relating to issues such as recruitment. CRF does not address the issue of staff diversity. 


\section{Ensuring access}

Under this heading we classified all issues relating to barriers to entering the healthcare organization. The dimensions that emerged concerned entitlement to care, the provision of understandable information, and issues concerning geographical and other aspects of accessibility. Some issues discussed in this domain reappear in the domain of 'care provision', because they are also relevant to the caregiving relationship.

\section{Entitlement to care}

Entitlement to care (i.e. whether patients are insured or are allowed to use national health services) is not mentioned in CLAS, JCR, CRF and EDS. This is understandable to the extent that entitlement is an issue covered by legislation and insurance rules, rather than by the policies of service providers. If service providers choose to give care outside the framework of formal entitlements, this is left to their own discretion. However, EQS goes a step further and charges organizations with a responsibility for patients who are not eligible for care: it urges that at the very least, steps should be taken to help them find appropriate care elsewhere. COER, which includes recommendations at health system level, makes a plea for "adequate entitlements to use of health services": concerning the role of service providers, it stresses that these must ensure that legislation is implemented properly and that all care providers are aware of existing rights.

\section{'Understandable' information}

Three approaches (CLAS, COER and EQS) stress that organizations should provide 'understandable' information in order to facilitate accessibility. This means providing information which is translated where necessary and is adapted to the health literacy level of the targeted populations.

\section{Geographical accessibility}

The importance of reducing geographical barriers to accessibility is briefly discussed in COER and EQS.

\section{Other aspects of accessibility}

In EDS and EQS two unique dimensions related to accessibility appeared. Firstly, EDS mentioned specific types of care (public health, vaccination and screening programs); secondly, EQS discussed the accessibility of organizations for specific 'disadvantaged' target groups such as HIV/ AIDS patients, disabled patients, and homeless people.

\section{Care provision}

Issues in this domain relate to the quality of care patients receive within an organization. Topics mentioned in the six approaches include: care that is responsive to the needs and wishes of patients, patient participation in the care process, overcoming communication barriers, providing 'understandable' patient information materials, trust, and patients' rights.

\section{Care responsive to needs and wishes}

All approaches underline the importance of this issue. The interpretation of this dimension is related to the different visions the approaches have concerning the nature of responsive care:

- CLAS and CRF focus on the cultural needs of patients, in accordance with their respective visions on responsive care ('culturally competent' and 'culturally responsive').

- JCR refers to 'additional' and 'unique' needs that should be integrated in the clinical process: "it is important for hospitals to be prepared to identify and address not just the clinical aspects of care, but also the spectrum of each patient's demographic and personal characteristics".

- COER focuses on the needs of migrants (broadly defined), going beyond cultural factors to consider social position, migration history and legal situation.

- EDS and EQS focus on needs resulting from patients' individual characteristics.

Apart from identifying needs, JCR also discusses the points in the care continuum at which they should be taken into account. Although all approaches emphasize the importance of taking patients' needs and wishes into account, they leave it up to the professional to reconcile the demands that patients or their relatives may make with the dictates of their professional conscience.

\section{Patient participation in the care process}

Five approaches (JCR, CRF, COER, EDS) explicitly refer to the importance of patient participation or involvement in the individual care process, for example in shared decision making about treatment and care planning [27]. CLAS and EQS do not refer explicitly to patient participation in this context; however, the standards they provide show that they too consider patients as active participants in their treatment.

\section{Overcoming communication barriers in patient-provider contact}

All approaches except EDS emphasize that organizations should systematically tackle language barriers in the service delivery setting, placing the onus on the organization to provide patients with language assistance where necessary. Various types of interpreting are recommended such as professional interpreters, bilingual staff or intercultural 
mediators; approaches differ according to which type they prefer. CLAS, JCR and COER explicitly advise against using untrained, informal interpreters such as family members. CLAS, JCR, CRF and EQS assert that organizations are responsible for ensuring the quality and competence of language assistance that is offered. CLAS and JCR mention that patients should be informed about their right to language assistance. JCR and EQS also discuss support to patients with other communication barriers (e.g. hearing or speech impairments).

\section{Understandable patient information materials}

With the exception of EDS, all approaches stress that patient information materials should be understandable for all patients, in terms of both language and level of health literacy. When suitable materials are not available, CLAS asserts that patients have a right to orally translated information. These points concern not only patient folders providing information about specific medical problems or treatments, but also consent forms and labeling of medicines.

\section{Trust}

The approaches discuss several issues related to building trust between users and service providers. The first of these is related to the environment within the health care organization: CLAS, JCR and EQS stress the importance of making this welcoming and inclusive. Some approaches include statements underlining the security of patients, stressing that patients should not be exposed to any dangers and mistreatment that might arise from their vulnerability. Phrases used include "patients are free from abuse, harassment, bullying, violence" (EDS); and "the patient has the right to be free from neglect, exploitation, and verbal, mental, physical and sexual abuse" (JC Requirements (see Table 1), p.54 [20]).

A second issue related to trust concerns conflict and grievance procedures. CLAS and JCR recommend that these procedures should be capable of identifying issues that concern organizations' responsiveness to diversity, and that such conflicts should be dealt with in a respectful manner (CLAS, JCR, and EDS). The issue of access by minority patients to grievance procedures is also discussed (CLAS, JCR), including the need for personnel dealing with complaints and grievances to receive proper training (CLAS).

\section{Patients' rights}

CLAS and JCR discuss the importance of informing patients about their rights. This concerns (among other things) the right in the US to receive language assistance (CLAS, JCR) and not to experience discrimination (JCR). JCR and EQS also note the importance of adapting informed consent procedures to the patients' needs (e.g. health literacy level).

\section{Patient and community participation at organizational level}

The sixth dimension identified in the approaches concerns the involvement of users and communities in health care at the organizational level. In this domain one dimension appeared: involving patients in the development of services. Patient participation in the care process was subsumed under the previous domain.

\section{Involving patients and communities in the development of services}

The issue of participation at the organizational level is discussed by all approaches. The first argument put forward in favor of such participation is that it results in more responsive care (CLAS, JCR). Another advantage named is that patients and communities can contribute to the implementation of changes (EDS). The approaches explicitly (CLAS, CRF, COER, EDS, EQS) or implicitly (JCR) assume that their target populations often belong to disadvantaged groups that may normally be less likely to take part in participation processes. The approaches therefore pay attention to the challenge of creating inclusive participation processes.

Four approaches explicitly mention community as well as patient participation (CLAS, JCR, CRF, EDS; COER speaks of migrant participation). The important difference between patient (or user) and community participation is that the latter brings in the voice of people who did not get into treatment. However, only CLAS and EDS explicitly regard it as important to build partnerships (e.g. with community representatives or organizations) in the community served by the health care organization. Their argument amounts to the following: a health care organization serves a community; therefore the community has to be enabled to exert influence on what happens in the organization through a collaborative process. In the other approaches, patients and community members are regarded as complementing each other (usually in the same sentence), without making clear the additional value of community participation.

\section{Promoting responsiveness}

Issues were classified in this domain if they concerned the promotion of responsive health care in the wider society. We identified one dimension, 'sharing information on experiences' in improving care for ethnic minority patients.

\section{Sharing information on experiences}

All approaches except CRF mention the importance of sharing experiences in promoting responsiveness. This is 
proposed with different aims in mind: to increase support for responsive care from the general public (COER), to demonstrate an organization's commitment (CLAS, JCR), or to enable organizations to learn from each other (CLAS, EQS). CRF and EQS take this theme a step further, by proposing that organizations should enter into active partnerships with others that promote equity within the health care system (e.g. in research and other collaborative activities).

\section{Unique issues}

Two issues were unique to particular approaches. JCR repeatedly mentioned the identification and addressing of patients' mobility needs (e.g. using a cane, guide dogs). EDS emphasized "supporting the workforce to remain healthy", which is in line with its focus on equality in the workforce.

\section{'Vertical' analysis (comparing approaches)}

In the foregoing section we discussed findings in terms of the domains (the rows of the matrix in Table 3). In what follows we analyze differences between the approaches represented in the columns, to obtain insight into the specific nature of each approach.

The linguistic issues in CLAS have a legal basis in the Civil Rights Act of 1964, which requires "entities that receive Federal financial assistance to take steps to ensure that limited English proficient individuals have meaningful access to the health services" [9], p. 10). CLAS has a very explicit vision on responsive health care, for example in the details provided about the content of training or the types of data that should be collected. Although unequal access is mentioned as a problem which might be reduced by providing appropriate services, the CLAS standards discuss only linguistic barriers to access.

JCR follows the steps in the clinical care process, which is explained by its origin in the Joint Commission standards for hospitals. JCR was developed as a supplement to existing standards, so it may have left out some issues already covered by existing Joint Commission standards. The standards do not embody an elaborated vision on 'responsiveness' beyond cultural competence, communication, and patient- and family-centered care. Accessibility is not operationalized in JCR. Interestingly, the international branch of the Joint Commission does consider accessibility as an important aspect of health care, as demonstrated for example by the standard stating that "the organization seeks to reduce physical, language, cultural, and other barriers to access and delivery of services" (p.42 [28]).

CRF focuses, like CLAS, mainly on cultural and linguistic issues. CRF offers quantitative and qualitative indicators (standards and measures) for measuring organizational responsiveness to diversity.

COER states to address governments rather than individual health care organizations, by discussing issues concerning organizational responsiveness to diversity without specifying precisely the division of responsibilities between levels. In keeping with the Council of Europe's historical role, COER is primarily concerned with the ethical and human rights dimensions of social and health issues.

EDS addresses accessibility and quality of care, but its vision of responsive care for 'protected groups' remains rather implicit. The implementation strategy elaborates on steps such as 'engage with local interests' and 'analyze performance'. The content of responsive care is only briefly described in terms of goals such as 'better outcomes for all' and 'improved patient access and experience' (see Table 2). One of the main objectives of EDS was to provide a tool for NHS commissioners to comply with the UK's 'Public Sector Equality Duty' (PSED). This is reflected in the envisaged target groups of EDS and explains the unique focus of EDS on equality among staff, in line with the aim of the PSED to eliminate discrimination and enhance equal opportunities throughout the public sector.

EQS emphasizes the vulnerability of certain patients, which can result from many factors - 'culture' being hardly mentioned as one of these. The focus is on patients' individual needs and characteristics, rather than their membership of specific ethnic, cultural or other groups. This approach seems to view 'patient centered care' as the best way to respond to diversity in care provision. Although EQS defines its target group as 'migrants and other vulnerable groups', most of the standards focus on issues relevant to migrants, which may be explained by the Task Force's origin in the Migrant Friendly Hospital network [25].

\section{Variations in the orientation of different approaches}

Only the European approaches address issues of access to health care in the sense of entitlement. A common feature of the non-European approaches is their emphasis on 'culture'. On closer examination, this seems to be mainly a question of how factors are labeled: in CLAS, for example, differences in socioeconomic or legal status are regarded as 'cultural' ones. In the European approaches the focus is on individual characteristics, which brings EQS close to the approach known as 'patient centered care' [29] (Saha, Beach, and Cooper have discussed the relation between 'patient centered' and 'culturally competent' care [30]). A possible shortcoming of this individualistic perspective is that the social position that characterizes members of certain groups (e.g. asylum seekers, irregular migrants) may be overlooked. COER and EQS are the only approaches that explicitly refer to 
Table 3 The approaches inserted in the analytic framework

\section{DOMAINS \&}

dimensions

Organizational

Commitment

Policy and

leadership

CLAS

a written strategic plan to provide culturally

competent care

*strategic plan is integrally

tied to the organization's

mission, principles, service

focus

Measuring and *initial and on-going selfimproving performance assessment of CLASrelated care

*integrate CLAS-related

measures into regular

quality improvement

programs (e.g. internal

audits)

*use data on individual

patients for needs

assessment, service

planning and quality

improvement

\section{Collecting data CLAS}

Data on the *maintain a current

population at demographic, cultural and

large

epidemiological profile,

and a needs assessment

of the community

Data on the ${ }^{*}$ collect data on individual

patient

patient's race, ethnicity,

population spoken/written language

in health record

*integrate CLAS-related *demonstrate leadership *implement a Cultural commitment to effective Responsiveness (CR)-plan communication (EC) $\begin{array}{ll}\text { cultural competence }(\mathrm{CC}), & \text { *integrate CR-plan into } \\ \text { and patient- and family } & \text { existing services' plans }\end{array}$ Responsiveness (CR)-plan
addressing the standards centered care (PFCC) and processes

.

CC, PFCC into existing

*have an advising structure with participation of culturally and linguistically diverse

(CALD) populations

allocation of financial

resources

*employ a cultural diversity staff member when CALD population > $20 \%$

*a baseline assessment whether organization meets unique patient

needs

*bligatory reporting on CR performance (on defined measures)

* perform research in outcomes (e.g. emergency presentations) for (ALD patients' care needs *analyze quality/risk management data for CALD patients

*report on CR performance in organization's regular performance reports *include CALD stakeholders in performance review

*use available population- *monitor community profile evel demographic data of and demographics surrounding community

*develop a system to collect patient-level data *collect data on patient

develop appropriate information strategies for data collection, reporting and sharing
COER

EDS

*organization as a whole must be 'culturally competent' *implement the

recommendations in a

sustainable, coordinated

and evidence based way

\section{*governments (in partnership} with other relevant organizations) collect background data and epidemiological data on

migrants

*evaluate existing services, identify existing problems, * conduct research to

identify problems, determin actions and evaluate interventions

EDS *leaders conduct and plan business so that equality is advanced *managers support and motivate staff to work culturally competent *recruit, develop and support strategic leaders

to advance equality outcomes

*integrate equality business planning

patient experiences

analyze performance, on results, and prepa (a) information systems (inc data on population level) objectives into mainstream

a specific plan to promote equity, integrated with existing accountability systems

*all organization plans promote equity

*continually identify and monitor access and barriers in access, and evaluate interventions for reducing access barriers (e.g. communication support services)

"use data on equity performance to improve equity in accessibility and quality

${ }^{*}$ collect or have access to data on health status and health inequalities of catchment area

*organization's systems can measure equity

performance

*identify patients' needs according to characteristics 
Table 3 The approaches inserted in the analytic framework (Continued)

\begin{tabular}{|c|c|c|c|c|c|c|}
\hline & $\begin{array}{l}\text { measures into patient satisfac- } \\
\text { tion } \\
\text { assessments }\end{array}$ & $\begin{array}{l}\text { record } \\
{ }^{*} \text { collect data on patient's } \\
\text { language and additional } \\
\text { patient-level information } \\
\text { (e.g. cultural, religious) } \\
{ }^{*} \text { Collect feedback from } \\
\text { patients, families }\end{array}$ & $\begin{array}{l}{ }^{*} \text { collect CALD patient } \\
\text { satisfaction data }\end{array}$ & & & $\begin{array}{l}\text { (health records include } \\
\text { information on } \\
\text { demographic characteristics } \\
\text { e.g. language, health } \\
\text { literacy level, ethnicity) }\end{array}$ \\
\hline Staff/workforce & CLAS & $J C R$ & CRF & COER & EDS & EQS \\
\hline $\begin{array}{l}\text { Staff } \\
\text { competencies }\end{array}$ & $\begin{array}{l}\text { *all staff receive on-going } \\
\text { education in providing CLAS }\end{array}$ & $\begin{array}{l}{ }^{*} \text { new and existing } \\
\text { training addresses issues } \\
\text { of EC, CC, PFCC }\end{array}$ & $\begin{array}{l}{ }^{*} \text { provide staff at all levels } \\
\text { with opportunities to } \\
\text { enhance their CR } \\
{ }^{*} \text { train staff*CR references } \\
\text { included in HRM policies and } \\
\text { practices (e.g. position } \\
\text { description) } \\
{ }^{*} \text { communication systems for } \\
\text { sharing information on CR }\end{array}$ & $\begin{array}{l}{ }^{*} \text { care professionals at various } \\
\text { levels should be trained in } \\
\text { accessibility issues and in } \\
\text { cultural competence }\end{array}$ & $\begin{array}{l}{ }^{*} \text { enable staff to be confident } \\
\text { and provide appropriate care } \\
\text { with support by training, } \\
\text { personal development and } \\
\text { performance appraisal }\end{array}$ & $\begin{array}{l}\text { *all staff is aware and } \\
\text { competent to address } \\
\text { inequities due to education } \\
\text { *specific training on equity } \\
\text { issues } \\
\text { *include equity issues in } \\
\text { organization's core education }\end{array}$ \\
\hline $\begin{array}{l}\text { Diversity in } \\
\text { workforce }\end{array}$ & $\begin{array}{l}\text { *strategies to recruit, retain } \\
\text { and promote diverse staff, } \\
\text { representative of } \\
\text { demographic characteristics } \\
\text { of service area } \\
{ }^{*} \text { diverse staff at all levels, } \\
\text { including diverse leadership }\end{array}$ & $\begin{array}{l}\text { *recruitment efforts to } \\
\text { increase a diverse } \\
\text { workforce that reflects the } \\
\text { patient population } \\
\text { *diverse workforce can } \\
\text { increase ethnic and } \\
\text { language concordance, } \\
\text { which may improve } \\
\text { communication }\end{array}$ & & $\begin{array}{l}{ }^{*} \text { recruitment policies should } \\
\text { ensure that the diversity of } \\
\text { general population is } \\
\text { reflected in the workforce } \\
\text { (mentioned as an example) }\end{array}$ & $\begin{array}{l}\text { *fair selection processes to } \\
\text { increase diversity of all } \\
\text { workforce } \\
\text { *equality in levels of pay } \\
\text { *staff can work in a safe } \\
\text { environment (e.g. free from } \\
\text { abuse, harassment etc.) } \\
\text { *flexible working options }\end{array}$ & $\begin{array}{l}\text { *fair and equitable workforce } \\
\text { policies and practices } \\
\text { *promote respect for dignity } \\
\text { of all staff and volunteers }\end{array}$ \\
\hline Ensuring access & CLAS & $J C R$ & CRF & COER & EDS & EQS \\
\hline $\begin{array}{l}\text { Entitlement to } \\
\text { care }\end{array}$ & & & & $\begin{array}{l}\text { *legislation concerning } \\
\text { entitlement is properly } \\
\text { implemented } \\
\text { *professionals at all levels are } \\
\text { aware of eligibility rights }\end{array}$ & & $\begin{array}{l}{ }^{*} \text { monitor situations of people } \\
\text { that are ineligible for care } \\
{ }^{*} \text { ensure health care to } \\
\text { people } \\
\text { ineligible for services by } \\
\text { providing appropriate } \\
\text { support }\end{array}$ \\
\hline $\begin{array}{l}\text { 'Understandable' } \\
\text { information }\end{array}$ & $\begin{array}{l}\text { *patient related materials and } \\
\text { post signage essential for } \\
\text { access should be made easily } \\
\text { understood } \\
\text { *offer and provide language } \\
\text { assistance services to all } \\
\text { patients with LEP, at all } \\
\text { contacts, in a timely manner } \\
\text { during all hours of operation }\end{array}$ & & & $\begin{array}{l}\text { *programs for migrants } \\
\text { should include knowledge } \\
\text { on health and illness, the way } \\
\text { the health system works, and } \\
\text { entitlements to health services } \\
\text { *promote interpretation and } \\
\text { translated materials to } \\
\text { improve accessibility }\end{array}$ & & $\begin{array}{l}\text { *in communicating with } \\
\text { people and providing } \\
\text { information on access issues, } \\
\text { health literacy and language } \\
\text { needs are taken into account }\end{array}$ \\
\hline $\begin{array}{l}\text { Geographical } \\
\text { accessibility }\end{array}$ & & & & $\begin{array}{l}\text { *inconvenient locations } \\
\text { should be reduced as far as } \\
\text { possible }\end{array}$ & & $\begin{array}{l}{ }^{*} \text { minimize architectural, } \\
\text { environmental and }\end{array}$ \\
\hline
\end{tabular}


Table 3 The approaches inserted in the analytic framework (Continued)

Other aspects of

accessibility
Care provision CLAS

to needs and (positive outcomes)

wishes

\section{understandable and}

respectful (patients values

taken into account) care

*care should be compatible

and practices, and preferred languages
Care responsive *patients receive effective

with cultural health beliefs
Patient

participation in

the care process

Overcoming communication

barriers in

patient-provider contact
$J C R$

Throughout the care continuum:

*ask for additional needs (e.g. cultural, religious) about unique patient needs o relevant providers *start patient-provider interaction with an introduction

*identify and accommodate cultural, religious, spiritual beliefs/practices th

influence care

*incorporate EC, CC, PFCC

concepts into care delivery

*Involve patients, families, *inclusive practice in care support persons in the care process along the care continuum.

*offer and provide language *identify patient's assistance services (including bilingual staff, interpreter services) at no costs to al patients with LEP, at all contacts, in a timely manner *inform patients of their right to receive language assistance *assure competence of language assistance by preferred language or other communication needs during admission *identify and monitor patient communication needs/status during care continuum, document this in patient record *ensure competence of language assistance

interpreters and bilingual staff communicate information during all hours of operation (including dietary, spiritual and other cultura practices)

CRF

practice in care planning (including dietary spiritual and other cultura ctices)

tation and revision use feedback/evaluation from patients to improve $C R$ *develop and use suitable

instruments for assessment e.g. clinical diagnosis) which incorporate cultural considerations

\section{*implement language}

services policy

*policies include directions

about role of interpreters and methods to reduce language family

*provide accredited

interpreters to patients who need one

*match employment of

in-house interpreters to

community demographics

*evaluate interpreter services goes beyond cultural factors, *remove accessibility barriers and reduce practical

difficulties (e.g. inconvenient opening times)

COER

*improve relevance and appropriateness of health

*offering the same services to everybody may result in users receivir

*services should be culturally competent (matched to needs of migrants from diverse backgrounds)

* culturally competent care e.g. social position, history, legal situation should also be taken into account

*adapt existing diagnostic and therapeutic procedures or invent new ones if

necessary

*promote participation of migrants in all activities concerning the provision of health services, including decision making processes

*high quality interpreting should be promoted barriers patients, carers and communities can readily access services

public health, vaccination and screening programs benefit all local communities/groups EDS

*assess individual patients health needs and provide appropriate and effective services

* discuss changes across services with patients and make transitions smoothly *strive for positive treatment experiences: being listened to, being respected, privacy and dignity are prioritized

\section{*involve patients as they} wish during the care continuum *ensure access to care for disadvantaged people

*provide outreach

information to

disadvantaged people on outreach services

EQS

*In needs assessments, delivery of care and at

discharge, patients' individual, family characteristics, experiences and living conditions are taken into account (incl. psychosocial needs)

workforce is able to take into account individual patients' ideas and experiences of health and illness in clinical practice and at discharge care is considerate and respectful of patients dignity, personal values, knowledge and beliefs regarding health care

*have a policy on overcoming language barriers *make professional interpreting services available and promote it modate communication needs of patients with e.g. hearing speech impairments *monitor quality of interpreting services/ communication support 
Table 3 The approaches inserted in the analytic framework (Continued)

\begin{tabular}{|c|c|c|c|c|c|c|}
\hline & & $\begin{array}{l}\text { provide language services } \\
{ }^{*} \text { inform patients of their } \\
\text { rights for an interpreter }\end{array}$ & & & & $\begin{array}{l}\text { *ensure staff ability to work } \\
\text { with interpreter/ } \\
\text { communication support staff }\end{array}$ \\
\hline $\begin{array}{l}\text { 'Understandable' } \\
\text { patient } \\
\text { information } \\
\text { materials }\end{array}$ & $\begin{array}{l}\text { *provide easily understood } \\
\text { patient related materials } \\
\text { (applications, consent forms) } \\
\text { and post signage in diverse } \\
\text { languages incl. directions to } \\
\text { facility services (diverse } \\
\text { language: languages of } \\
\text { commonly encountered } \\
\text { groups/groups represented in } \\
\text { the service area) } \\
\text { *take into account culture } \\
\text { and health literacy levels } \\
\text { *persons from small } \\
\text { language groups have the } \\
\text { right to oral translation }\end{array}$ & $\begin{array}{l}\text { *provide patient } \\
\text { education materials and } \\
\text { instructions that meet } \\
\text { patients' needs (health } \\
\text { literacy, language) during } \\
\text { assessment, treatment } \\
\text { and discharge } \\
\text { *support patient's ability } \\
\text { to understand/act on } \\
\text { health information } \\
\text { *determine needs for } \\
\text { assistance with admission } \\
\text { forms (health literacy) }\end{array}$ & $\begin{array}{l}\text { *have appropriate } \\
\text { translations of signage, } \\
\text { patient forms, education } \\
\text { materials for predominant } \\
\text { language groups using } \\
\text { services }\end{array}$ & $\begin{array}{l}\text { *promote high quality } \\
\text { translated written information }\end{array}$ & & $\begin{array}{l}\text { *provide easily understood } \\
\text { written material and signage } \\
\text { taking health literacy and } \\
\text { language needs into account }\end{array}$ \\
\hline Trust & $\begin{array}{l}\text { Conflict \& grievance } \\
{ }^{*} \text { conflict/grievance } \\
\text { procedures are culturally } \\
\text { sensitive } \\
{ }^{*} \text { conflict/grievance } \\
\text { procedures can identify, } \\
\text { prevent, resolve cross-cultural } \\
\text { conflicts/complaints } \\
{ }^{*} \text { staff handling complaints } \\
\text { should receive cultural } \\
\text { competence training } \\
{ }^{*} \text { monitor culturally or } \\
\text { linguistically related complaints } \\
\text { Atmosphere } \\
{ }^{*} \text { create a welcoming and } \\
\text { inclusive environment }\end{array}$ & $\begin{array}{l}\text { Conflict \& grievance } \\
\text { *accessible complaints } \\
\text { system (language, non- } \\
\text { writing) } \\
\text { *complaints are not being } \\
\text { subjected to coercion, } \\
\text { discrimination, reprisal, or } \\
\text { unreasonable interruption } \\
\text { of care Atmosphere } \\
{ }^{*} \text { create an environment } \\
\text { that is inclusive of all } \\
\text { patients } \\
{ }^{*} \text { patient has the right to } \\
\text { be free of neglect, } \\
\text { exploitation and abuse } \\
\text { (regular JC standards, } \\
\text { chapter: Rights and } \\
\text { Responsibilities of the } \\
\text { Individual) }\end{array}$ & $\begin{array}{l}\text { Conflict \& grievance } \\
{ }^{*} \text { monitor number of } \\
\text { complaints lodged by CALD } \\
\text { consumers/patients. }\end{array}$ & & $\begin{array}{l}\text { Conflict \& grievance } \\
{ }^{*} \text { complaints should be } \\
\text { handled respectfully and } \\
\text { efficiently Atmosphere } \\
{ }^{*} \text { create a safe environment, } \\
\text { without threat of dignity of } \\
\text { denial of individual identity }\end{array}$ & $\begin{array}{l}\text { Atmosphere } \\
{ }^{*} \text { Create a safe environment, } \\
\text { with respect for patient's } \\
\text { dignity and identity } \\
{ }^{*} \text { Create an environment } \\
\text { inclusive for all patients }\end{array}$ \\
\hline Patients' rights & $\begin{array}{l}\text { *provide notices in diverse } \\
\text { language of a variety of } \\
\text { patients' rights (including } \\
\text { right for language assistance) }\end{array}$ & $\begin{array}{l}\text { *inform patients of their } \\
\text { rights (interpreter, } \\
\text { accommodation for } \\
\text { disability, be free from } \\
\text { discrimination, etc.) } \\
\text { *tailor the informed } \\
\text { consent process to meet } \\
\text { patient needs (related to } \\
\text { low HL) }\end{array}$ & & & & $\begin{array}{l}\text { *accommodate patients' } \\
\text { diverse needs in informed } \\
\text { consent procedure }\end{array}$ \\
\hline
\end{tabular}

efficiently Atmosphere dignity and identity

*reate a safe environment, ${ }^{*}$ create an environmen

without threat of dignity of inclusive for all patients

subjected to coercion

unreasonable interruption

*reate an environment

e free of neglect 
Table 3 The approaches inserted in the analytic framework (Continued)

\begin{tabular}{|c|c|c|c|c|c|c|}
\hline $\begin{array}{l}\text { Patient and } \\
\text { community } \\
\text { participation at } \\
\text { organizational } \\
\text { level }\end{array}$ & CLAS & $J C R$ & CRF & COER & EDS & EQS \\
\hline $\begin{array}{l}\text { Involving } \\
\text { patients and } \\
\text { communities } \\
\text { in the } \\
\text { development } \\
\text { of services }\end{array}$ & $\begin{array}{l}\text { *utilize a variety mechanisms } \\
\text { to facilitate community and } \\
\text { patient involvement in } \\
\text { designing and implementing } \\
\text { services } \\
\text { *develop participatory, } \\
\text { collaborative partnerships } \\
\text { with communities }\end{array}$ & $\begin{array}{l}\text { *be involved and } \\
\text { engaged with patients, } \\
\text { families and the } \\
\text { community to identify } \\
\text { needs for new/modified } \\
\text { services } \\
\text { "collect feedback from } \\
\text { patient, families and } \\
\text { communities }\end{array}$ & $\begin{array}{l}\text { *CALD consumer, carer and } \\
\text { community members are } \\
\text { involved in the planning, } \\
\text { improvement and review of } \\
\text { programs and services on an } \\
\text { on-going basis } \\
\text { *advice of participation struc- } \\
\text { tures is taken into account } \\
\text { *facilitate different degrees of } \\
\text { participation from CALD } \\
\text { consumers, carers, community } \\
\text { *develop partnerships with } \\
\text { ethno-specific community } \\
\text { organizations }\end{array}$ & $\begin{array}{l}\text { *promote participation of } \\
\text { migrants in designing, } \\
\text { evaluating, and carrying out } \\
\text { research on migrant health } \\
\text { and health care } \\
\text { *promote participation of } \\
\text { migrants in developing and } \\
\text { implementing new measures }\end{array}$ & $\begin{array}{l}\text { *identify local interests } \\
\text { (including patients, } \\
\text { communities) that need to } \\
\text { be involved in implementing } \\
\text { EDS } \\
\text { *share assembled } \\
\text { information with local } \\
\text { interests so they participate } \\
\text { in analyzing performance } \\
\text { and setting objectives } \\
\text { *agree roles with local } \\
\text { authority (e.g. services that } \\
\text { share the same clientele) }\end{array}$ & $\begin{array}{l}\text { *identify service users at } \\
\text { risk } \\
\text { for exclusion from } \\
\text { participatory processes, } \\
\text { promote their participation } \\
{ }^{*} \text { identify and overcome } \\
\text { barriers to participation } \\
{ }^{*} \text { monitor and evaluate } \\
\text { participatory processes } \\
\text { *use feedback to improve } \\
\text { services and share results of } \\
\text { participation with public }\end{array}$ \\
\hline $\begin{array}{l}\text { Promoting } \\
\text { Responsiveness }\end{array}$ & CLAS & $J C R$ & CRF & COER & EDS & EQS \\
\hline $\begin{array}{l}\text { Sharing } \\
\text { information on } \\
\text { experiences }\end{array}$ & $\begin{array}{l}\text { *make information available } \\
\text { to public on progress and } \\
\text { innovations in implementing } \\
\text { CLAS } \\
\text { *inform community, own } \\
\text { organization (for } \\
\text { institutionalizing CLAS) and } \\
\text { other organizations to learn } \\
\text { from each other }\end{array}$ & $\begin{array}{l}\text { *share information with } \\
\text { surrounding community } \\
\text { about efforts to meet } \\
\text { unique patients' needs to } \\
\text { demonstrate commitment }\end{array}$ & $\begin{array}{l}\text { *undertake research to } \\
\text { develop new and improved } \\
\text { initiatives and resources for } \\
\text { CR }\end{array}$ & $\begin{array}{l}\text { *inform public adequately } \\
\text { about issues concerning } \\
\text { migrant health }\end{array}$ & $\begin{array}{l}\text { *share assembled evidence } \\
\text { on equality performance } \\
\text { with local interests (e.g. } \\
\text { patients, communities), so } \\
\text { they can take part in } \\
\text { analysing performance and } \\
\text { set goals } \\
\text { *publish accomplishments } \\
\text { (grades) and equality } \\
\text { objectives so they are } \\
\text { accessible for local interests }\end{array}$ & $\begin{array}{l}\text { *be a participant in networks, } \\
\text { research initiatives which } \\
\text { promote equity } \\
\text { *disseminate results of } \\
\text { research/practice related to } \\
\text { equity } \\
\text { *build solid relationships/ } \\
\text { networks with community- } \\
\text { based service providers } \\
\text { *ensure that equity is } \\
\text { reflected in all partnership } \\
\text { and service contracts }\end{array}$ \\
\hline \multirow[t]{2}{*}{ Unique issues } & \multirow[t]{2}{*}{ CLAS } & $J C R$ & \multirow[t]{2}{*}{ CRF } & \multirow[t]{2}{*}{ COER } & EDS & \multirow[t]{2}{*}{ EQS } \\
\hline & & $\begin{array}{l}\text { *identify and address } \\
\text { mobility needs (e.g. cane, } \\
\text { guiding dogs) }\end{array}$ & & & $\begin{array}{l}\text { *support workforce to } \\
\text { remain healthy, focus on } \\
\text { major health and lifestyle } \\
\text { issues that affect individual } \\
\text { and wider population }\end{array}$ & \\
\hline
\end{tabular}


'migrants' and take into account the vulnerability that results from having different kinds of migrant status (asylum seeker, irregular migrant, labor migrant etc.).

\section{Discussion}

From this content analysis of six approaches to organizational responsiveness to diversity a broad consensus emerged on what health care organizations need to do to meet the differing health care needs of diverse patient populations. The following domains were almost universally regarded as important for creating responsive organizations: organizational commitment, collecting and analyzing data to provide empirical evidence on inequalities and needs, development of a competent and diverse workforce, ensuring access for all users, ensuring responsiveness in care provision, fostering patient and community participation, and actively promoting the ideal of responsiveness (see Tables 3 and 4 for the synthesis of the content of these domains).

The described elements for organizations to address might be used as guidance for implementation of diversity responsive health care. The elements show that all stakeholders, including all patients and their communities, should be involved in developing improved services. This consensus opens the way to wider implementation of organizational responsiveness to diversity.

Table 4 Description of classified domains and dimensions, and coverage of domains/dimensions by the six approaches (the orange cells visualize table 3's empty cells meaning that this dimension is not covered by that approach)

\begin{tabular}{|c|c|c|c|c|c|c|c|c|}
\hline \multirow[t]{2}{*}{ DOMAINS } & \multirow[t]{2}{*}{ Dimensions } & \multirow[t]{2}{*}{ CLARIFICATION OF THE DOMAINS AND DIMENSIONS } & \multicolumn{6}{|c|}{ (the orange cells visualize 'empty cells' from table 3 ) } \\
\hline & & & CLAS & JCR & CRF & COER & EDS & EQS \\
\hline \multirow[t]{3}{*}{$\begin{array}{l}\text { ORGANIZATIONAL } \\
\text { COMMITMENT }\end{array}$} & & $\begin{array}{l}\text { The obligations health care organizations impose on themselves about providing } \\
\text { diversity responsive care. }\end{array}$ & & & & & & \\
\hline & Policy and leadership & $\begin{array}{l}\text { Organizations' explicit commitment to provide diversity responsive care, } \\
\text { demonstrated in policies and leadership and integrated in regular policies. }\end{array}$ & & & & & & \\
\hline & $\begin{array}{l}\text { Measuring and improving } \\
\text { performance }\end{array}$ & $\begin{array}{l}\text { Measuring organizations' performance related to diversity responsive care and } \\
\text { improving performance based on the findings. }\end{array}$ & & & & & & \\
\hline \multirow[t]{3}{*}{ COLLECTING DATA } & & $\begin{array}{l}\text { Collecting data to provide evidence on equity of access and of quality of care for } \\
\text { diverse populations. }\end{array}$ & & & & & & \\
\hline & $\begin{array}{l}\text { Data collection on the } \\
\text { population at large }\end{array}$ & $\begin{array}{l}\text { Data collection on demographics, characteristics relevant for service use, and } \\
\text { health of the population living in the geographical area served by the health care } \\
\text { organization. }\end{array}$ & & & & & & \\
\hline & $\begin{array}{l}\text { Data collection on the } \\
\text { patient population }\end{array}$ & Data collection of the patients being served by the health care organization. & & & & & & \\
\hline \multirow[t]{3}{*}{ STAFF/WORKFORCE } & & $\begin{array}{l}\text { Issues related to the care providers, the management and support workers, that } \\
\text { work at a health care organization }\end{array}$ & & & & & & \\
\hline & Staff competencies & $\begin{array}{l}\text { Improving competencies of staff working at a health care organization to provide } \\
\text { responsive care (e.g. by training and other support). }\end{array}$ & & & & & & \\
\hline & Diversity in workforce & $\begin{array}{l}\text { Creating a demographically diverse workforce of a health care organization and } \\
\text { ensure equal opportunities among all. }\end{array}$ & & & & & & \\
\hline \multirow[t]{5}{*}{ ENSURING ACCESS } & & $\begin{array}{l}\text { People that need healthcare can access health care services in a timely manner } \\
\text { and without barriers. }\end{array}$ & & & & & & \\
\hline & Entitlement to care & $\begin{array}{l}\text { Implementation of legislation on entitlements for the use of health services for } \\
\text { specific groups (e.g. undocumented migrants). }\end{array}$ & & & & & & \\
\hline & $\begin{array}{l}\text { 'Understandable' } \\
\text { information }\end{array}$ & $\begin{array}{l}\text { Providing information adapted to language and health literacy needs of diverse } \\
\text { patient populations to facilitate access. }\end{array}$ & & & & & & \\
\hline & Geographical accessibility & Reducing geographical barriers to access. & & & & & & \\
\hline & $\begin{array}{l}\text { Other aspects of } \\
\text { accessibility }\end{array}$ & Issues on ensuring accessibility not discussed in the dimensions above & & & & & & \\
\hline \multirow[t]{8}{*}{ CARE PROVISION } & & Providing good quality health care in the context of patients' diversity. & & & & & & \\
\hline & $\begin{array}{l}\text { Care responsive to needs } \\
\text { and wishes }\end{array}$ & Providing care that is responsive to diverse patients' needs and wishes. & & & & & & \\
\hline & $\begin{array}{l}\text { Patient participation in the } \\
\text { care process }\end{array}$ & Patient participation or involvement in the individual care process. & & & & & & \\
\hline & $\begin{array}{l}\text { Overcoming } \\
\text { communication barriers in } \\
\text { patient-provider contact }\end{array}$ & Removing communication barriers in the patient-provider contact. & & & & & & \\
\hline & 'Understandable' patient & Removing barriers in understanding patient information materials (with regard to & & & & & & \\
\hline & information materials & language and health literacy level). & & & & & & \\
\hline & Trust & $\begin{array}{l}\text { Building trust between service users and service providers with regard to patient } \\
\text { diversity. }\end{array}$ & & & & & & \\
\hline & Patients' rights & Inform patients of their rights. & & & & & & \\
\hline \multirow[t]{2}{*}{$\begin{array}{l}\text { PATIENT AND } \\
\text { COMMUNITY } \\
\text { PARTICIPATION AT } \\
\text { ORGANIZATIONAL } \\
\text { LEVEL }\end{array}$} & & $\begin{array}{l}\text { The process that enables patients and/or communities to participate in planning, } \\
\text { developing and delivering health services at organizational level. }\end{array}$ & & & & & & \\
\hline & $\begin{array}{l}\text { Involving patients and } \\
\text { communities in the } \\
\text { development of services }\end{array}$ & $\begin{array}{l}\text { Efforts to include all patients and communities (including those of risk to be } \\
\text { excluded) in participation activities for development of services. }\end{array}$ & & & & & & \\
\hline \multirow[t]{2}{*}{$\begin{array}{l}\text { PROMOTING } \\
\text { RESPONSIVENESS }\end{array}$} & & $\begin{array}{l}\text { Furthering responsive health care in the society to which a health care } \\
\text { organization belongs. }\end{array}$ & & & & & & \\
\hline & $\begin{array}{l}\text { Sharing information on } \\
\text { experiences }\end{array}$ & $\begin{array}{l}\text { Disseminating experiences with providing diversity responsive health care to } \\
\text { stakeholders/society. }\end{array}$ & & & & & & \\
\hline
\end{tabular}


There were, however, also some variations in the operationalization of diversity responsive health care, related to different scopes, contexts and types or definitions of diversity. The non-European approaches focus on improving quality of care and linguistic accessibility in the fight against health disparities, while the issue of 'entitlement to care' seems overlooked. This is remarkable since (lack of) health insurance coverage explains substantial proportions of disparities in health care in the US [31]. The National Health Interview Study 2012 found that while $7.6 \%$ of white respondents had been uninsured for more than one year, this percentage was 23.6 in the Hispanic population, 11.7 in the black population, and 11.3 in the Asian population [32]. Although entitlement to care is usually regulated by governments rather than service providers, approaches that aim to reduce disparities should at least acknowledge the importance of entitlement.

The consensus we found between these six approaches relates to some emerging debates in the area of diversity responsive care. First, there is the debate on the relative importance of individual patient characteristics versus cultural or group characteristics. Adapting routine health and preventive care services [33] using the concept of 'patient centered care' is a step in the right direction of acknowledging diversity among all patients. However, patient centeredness focuses on acknowledging the uniqueness of patients. This individualistic approach to diversity carries a risk, because the most serious inequities in health care are strongly associated with differences in group membership and social situation. This was illustrated in Philimore's study on maternity services in an era of superdiversity, which showed that immigration status was one of the most important factors in determining problems with maternity services [34]. Being an asylum seeker or undocumented migrant is neither a cultural characteristic nor a personal one - it is a social position, with important consequences for health and access to health care. An exclusive on 'culture' is misleading, and that diversity responsive health care means that cultural aspects, social position and individual needs all have to be taken into account.

A second debate touching the topic of this paper is the debate of discrimination versus diversity responsive health care. The latter explicitly requires care providers to differentiate between patients (if relevant for equal chances of optimal health care outcomes), whereas the non-discrimination principle prescribes not making a distinction between patients (under equal circumstances) [35]. Dovidio et al. report that overt racism among care providers has become rare, but that explicit egalitarian attitudes prevent care providers and organizations to diversify care provision when it is necessary [36]. The fear of prejudice and stereotyping may thus lead to suboptimal care. The topic of discrimination was only briefly touched upon in most of the six analyzed approaches.
We believe that future approaches should elaborate more on this topic so that health care organizations will have more guidance in dealing with this dilemma.

Our analysis had its limitations. The sample of approaches was confined to the US, Australia and Europe. We explicitly did not aim at a complete review by sampling and comparing all existing approaches, because too many have been developed to make that practical. It is possible that valuable approaches were missed. However, the six approaches included showed considerable consensus regarding the important elements of care that is responsive to diversity, and data were saturated. Because of variations in the level of detail provided by the approaches, classifying them may not fully do justice to the visions or ideas behind the approaches. For example, EDS contains only a rudimentary conceptualization of responsiveness, but it may be that within the NHS other documents elaborate this concept in more detail.

\section{Conclusion}

This study demonstrated that a considerable degree of consensus exists about the issues that health care organizations need to address in order to adequately respond to diversity. This creates the opportunity to move forward, to resolve purely terminological differences and to help health care organizations to respond to the diversity that is present in modern societies.

\section{Abbreviations}

CLAS: Culturally and Linguistically Appropriate Services (referring to the National Standards for Culturally and Linguistically Appropriate Services in Health Care; JCR: Joint Commission Roadmap (referring to Advancing Effective Communication, Cultural Competence, and Patient- and Family Centered Care: A Roadmap for Hospitals; CRF: Cultural Responsiveness Framework (referring to Cultural Responsiveness Framework. Guidelines for Victorian health services; COER: Council of Europe Recommendations (referring to Recommendation of the committee of ministers to member states on mobility, migration and access to health care; EDS: The Equality Delivery System; NHS: National Health Service; EQS: The Equity Standards (referring to Standards for Equity in Health Care for Migrants and other Vulnerable Groups; WHO-HPH: World Health Organization - Health Promoting Hospitals Network; HRM: Human Resource Management; PSED: Public Sector Equality Duty.

\section{Competing interests}

MCS, MLE-B and DI are members of the Task Force on Migrant Friendly and Culturally Competent Health Care which is the expert group that developed the Equity Standards (EQS).

DI was a member of the committee that drafted the Council of Europe Recommendations (COER). MCS's salary as a researcher at the time of this study was paid from funding provided by the Netherlands Organization for Health Research and Development (ZonMw; grant number 510000001). The funders had no role in study design, data collection and analysis, decision to publish, or preparation of the manuscript.

\section{Authors' contributions}

DI developed the idea for the present comparison. MCS, MLE-B and DI developed the research design. MCS was the primary data analyst. All analyses were checked and discussed with MLE-B and DI. MCS drafted the manuscript. All authors provided input to the manuscript and approved of the final version. Supervision was provided by KS, MLE-B and DI. All authors read and approved the final manuscript. 


\section{Author details}

${ }^{1}$ Department of Public Health, Academic Medical Center, University of Amsterdam, P.O. Box 227001100 DE Amsterdam, The Netherlands. ${ }^{2}$ Centre for Social Science and Global Health (SSGH), University of Amsterdam, Amsterdam, The Netherlands.

\section{Received: 30 January 2015 Accepted: 30 October 2015} Published online: 16 November 2015

\section{References}

1. Smedley BD, Stith AY, Nelson AR. Unequal treatment: confronting racial and ethnic disparities in health care. Washington, DC: The National Academies Press; 2003.

2. Vaccarino V, Rathore SS, Wenger NK, Frederick PD, Abramson JL, Barron HV et al. Sex and racial differences in the management of acute myocardial infarction, 1994 through 2002. N Engl J Med. 2005;353(7):671-82. doi:10.1056/NEJMsa032214

3. Aarts MJ, Koldewijn EL, Poortmans PM, Coebergh JW, Louwman M. The impact of socioeconomic status on prostate cancer treatment and survival in the southern Netherlands. Urology. 2013;81(3):593-9. doi:10.1016/ j.urology.2012.11.011.

4. de Bruijne MC, van Rosse F, Uiters E, Droomers M, Suurmond J, Stronks K, et al. Ethnic variations in unplanned readmissions and excess length of hospital stay: a nationwide record-linked cohort study. Eur J Public Health. 2013;23(6):964-71. doi:10.1093/eurpub/ckt005.

5. Fransen MP, Essink-Bot ML, Vogel I, Mackenbach JP, Steegers EA, Wildschut HI. Ethnic differences in informed decision-making about prenatal screening for Down's syndrome. J Epidemiol Community Health. 2010;64(3):262-8. doi:10.1136/jech.2009.088237

6. Betancourt JR. Cross-cultural medical education: conceptual approaches and frameworks for evaluation, Academic Medicine. J Assoc Am Med Colleges. 2003;78(6):560-9.

7. Seeleman C, Suurmond J, Stronks K. Cultural competence: a conceptual framework for teaching and learning. Med Educ. 2009;43(3):229-37. doi:10.1111/j.1365-2923.2008.03269.x.

8. Chiarenza A. Developments in the concept of 'Cultural Competence'. In: Ingleby D, Chiarenza A, Deville W, Kotsioni I, editors. Inequalities in health care for migrants and ethnic minorities. Antwerp: Garant Publishers; 2012. p. 66-81.

9. Office of Minority Health, US Department of Health and Human Services. National Standards for Culturally and Linguistically Appropriate Services in Health Care: Final Report. Washington D.C.: Office of Minority Health, US Dept. of Health and Humans Services; 2001. http://minorityhealth.hhs.gov/ assets/pdf/checked/finalreport.pdf. Accessed 29 Jan 2015.

10. Goode TD, Like RC. Advancing and sustaining cultural and linguistic competence in the American health system: challenges, strategies, and lessons learned. In: Ingleby D, Chiarenza A, Deville W, Kotsioni I, editors. Inequalities in health care for migrants and ethnic minorities. Antwerp: Garant Publishers; 2012. p. 49-65.

11. Office of Minority Health, US Department of Health and Human Services. National standards for Culturally and Linguistically Appropriate Services in health and health care: A blueprint for advancing and sustaining CLAS policy and practice. Washington D.C.: Office of Minority Health, US Department of Health and Humans Services; 2013. https:// www.thinkculturalhealth.hhs.gov/pdfs/EnhancedCLASStandardsBlueprint.pdf. Accessed 29 Jan 2015

12. Bischoff A, Chiarenza A, Loutan L. "Migrant-friendly hospitals": a European initiative in an age of increasing mobility. World Hosp Health Serv. 2009;45(3):7-9.

13. Mosko MO, Gil-Martinez F, Schulz H. Cross-cultural opening in German outpatient mental healthcare service: an exploratory study of structural and procedural aspects. Clin Psychol Psychother. 2013;20(5):434-46. doi:10.1002/ cpp.1785.

14. Domenig D. The concept of transcultural competence (Das konzept der transkulturelle kompetenz). In: Domenig D, editor. Transkulturelle kompetenz: lehrbuch für pflege-, gesundheits- und sozialberufe. Bern: Verlag Hans Huber; 2007. p. 165-89.

15. Renschler I, Cattacin S. Comprehensive "Difference Sensitivity" in health systems. Migration and health: difference sensitivity from an organisational perspective. Holmbergs: Malmö; 2007.
16. Cross TL, Bazron BJ, Denis KW. R IM. Towards a culturally competent system of care: A monograph on efective services for minority children who are severely emotionaly disturbed. Washington, D.C.: Georgetown University Child Development Center, CASSP Technical Assistance Center; 1989.

17. Grant J, Parry Y, Guerin P. An investigation of culturally competent terminology in healthcare policy finds ambiguity and lack of definition. Aust N Z J Public Health. 2013;37(3):250-6. doi:10.1111/1753-6405.12067.

18. Hollinsworth D. Forget cultural competence; Ask for an autobiography, Social Work Education. Int J. 2013;32(8):1048-60. doi:10.1080/ 02615479.2012 .730513$.

19. Truong M, Paradies $Y$, Priest N. Interventions to improve cultural competency in healthcare: a systematic review of reviews. BMC Health Serv Res. 2014;14:99. doi:10.1186/1472-6963-14-99.

20. The Joint Commission. Advancing effective communication, cultural competence, and patient- and family-centered care: A roadmap for hospitals. Oakbrook Terrace, IL: The Joint Commission; 2010. http:// www.jointcommission.org/assets/1/6/ aroadmapforhospitalsfinalversion727.pdf. Accessed 29 Jan 2015.

21. Department of Health, State of Victoria. Cultural responsiveness framework. Guidelines for Victorian health services: Rural and Regional Health and Aged Care Services, Victorian Government, Department of Health, Melbourne, Victoria; 2009. http://www.health.vic.gov.au/_data/assets/pdf_file/0008/ 381068/cultural_responsiveness.pdf. Accessed 29 Jan 2015.

22. Council of Europe. Draft Explanatory Memorandum of the draft Recommendation CM/Rec(2011) of the Committee of Ministers to member states on mobility, migration and access to health care; 2011. https:// wcd.coe.int/ViewDoc.jsp?Ref=CM(2011)141\&Language=lanEnglish\&Ver=add \&Site=COE\&BackColorlnternet=DBDCF2\&BackColorlntranet=FDC864\&Back ColorLogged=FDC864. Accessed 29 Jan 2015.

23. Council of Europe. Recommendation CM/Rec(2011)13 of the Committee of Ministers to member states on mobility, migration and access to health care; 2011. https://wcd.coe.int/ViewDoc.jsp?id=1872157. Accessed 29 Jan 2015.

24. NHS Equality and Diversity Council. The Equality Delivery System for the NHS. National Health Services; 2012.

25. Task Force on Migrant Friendly and Culturally Competent Health care. Standards for equity in health care for migrants and other vulnerable groups;2013. http://wwwold.ausl.re.it/HPH/FrontEnd/Home/ Default.aspx?channel_id=38. Accessed 29 Jan 2015.

26. Whitehead M. The concepts and principles of equity and health Copenhagen: World Health Organization, Regional Office for Europe1990 Contract No:: EUR/ICP/RPD 414.

27. Suurmond J, Seeleman C. Shared decision-making in an intercultural context. Barriers in the interaction between physicians and immigrant patients. Patient Educ Couns. 2006;60(2):253-9. doi:10.1016/j.pec.2005.01.012.

28. Joint Commission International. Joint Commission International Accreditation standards for hospitals. 2011.

29. Committee on Quality of Health Care in America, Institute of Medicine Crossing the quality chasm: A new health system for the 21st century. Washington, D.C: The National Academies Press; 2001.

30. Saha S, Beach MC, Cooper LA. Patient centeredness, cultural competence and healthcare quality. J Natl Med Assoc. 2008;100(11):1275-85.

31. Kirby JB, Taliaferro G, Zuvekas SH. Explaining racial and ethnic disparities in health care. Med Care. 2006;44(5 Suppl):164-72. doi:10.1097/ 01.mlr.0000208195.83749.c3.

32. Martinez ME, Cohen RA. Health insurance coverage: Early release of estimates from the national health interview survey, January-September 2012. 2013.

33. Razum O, Spallek J. Addressing health-related interventions to immigrants: migrant-specific or diversity-sensitive? Int J Public Health. 2014;59(6):893-5. doi:10.1007/s00038-014-0584-4

34. Phillimore J. Delivering maternity services in an era of superdiversity: the challenges of novelty and newness. Ethnic Racial Stud. 2015;38(4):568-82.

35. van de Vathorst $S$, Willems $D$, Essink-Bot ML. The contribution of the capabilities approach to reconciling culturally competent care and nondiscrimination. Am J Bioeth. 2013:13(8):47-8. doi:10.1080/ 15265161.2013.802065

36. Dovidio JF, Penner LA, Albrecht TL, Norton WE, Gaertner SL, Shelton JN. Disparities and distrust: the implications of psychological processes for understanding racial disparities in health and health care. Soc Sci Med. 2008;67(3):478-86. doi:10.1016/j.socscimed.2008.03.019. 
37. Council of Europe. Statute of the Council of Europe. European Treaty Series 1. 1949. Available: conventions.coe.int//reaty/en/Treaties/Word/001.doc. Accessed 27 August 2015.

38. Home Office. Public sector equality duty. 2012. Available: https:// www.gov.uk/guidance/equality-act-2010-guidance. Accessed 27 August 2015.

Submit your next manuscript to BioMed Central and take full advantage of:

- Convenient online submission

- Thorough peer review

- No space constraints or color figure charges

- Immediate publication on acceptance

- Inclusion in PubMed, CAS, Scopus and Google Scholar

- Research which is freely available for redistribution 